\title{
The impact of digital entrepreneurship on the environmental quality of agricultural companies: Evidence from agricultural companies in Jordan valley
}

\author{
Elham Alhiary $^{\mathbf{a}^{*}}$ and Worood Alsaket ${ }^{\mathrm{a}}$
}

${ }^{a}$ Al-Balqa Applied University, Jordan

\begin{tabular}{l} 
C H R O N I C L E \\
\hline Article history: \\
Received: December 5, 2020 \\
Received in revised format: \\
January 26 2021 \\
Accepted: April 3, 2021 \\
Available online: \\
April 5, 2021 \\
\hline Keywords: \\
Digital entrepreneurship \\
Environmental quality \\
Agricultural companies
\end{tabular}

Agricultural companies

\begin{abstract}
A B S T R A C T
The present study aimed to explore the impact of digital entrepreneurship on the environmental quality of agricultural companies. The population consists of 20 big and middle sized companies. The sample consists of 85 individuals. A questionnaire was used for data collection. SPSS program was used. The dimensions of digital entrepreneurship are: (digital knowledge management, digital business environment management, and electronic leadership skills). The dimensions of environmental quality are: (top management commitment, ongoing improvement, and team work). Several results were reached. For instance, it was found that agricultural companies practice digital knowledge management for improving the environmental quality. However, such companies have been facing many challenges. Such challenges include: the fluctuations in the cash flow. The researcher recommends providing talented employees in agricultural companies with incentives. That shall enable those companies to keep up with the latest development in the field.
\end{abstract}

(c) 2021 by the authors; licensee Growing Science, Canada

\section{Introduction}

The term (total quality environmental management) appeared officially in 1990. It has been highly used during the last couple of years (Nambisan, 2017). That's attributed to the initiative launched by Global Environmental Management (Biscotti et al, 2018). Through the latter initiative, more than 20 big-sized US companies decided to practice (total quality environmental management) willingly when carrying out their operations (Passetti et al., 2018). They decided that because providing much attention to environmental quality shall enable companies to achieve sustainable success and economic growth (Biscotti et al., 2018). Providing such attention shall enable companies to reduce the severity of the negative impacts that their operations have on the environment. According to Albuhisi and Abdallah (2018), the International Organization for Standardization (ISO) set a series of international standards in collaboration with several companies in 1996. The latter standards are related to the environmental quality. They were upgraded in 2014 and 2015. Today, companies of all types and sizes seek meeting the environmental quality-related standards that are issued by ISO. Through meeting the latter standards, companies can get international certificates (Boren, 2016). During the $21^{\text {st }}$ century, the fourth industrial revolution led to making dramatic changes to the procedures adopted by companies for carrying out operations (Nambisan, 2017). It encouraged the management of companies to keep up with the latest digital technologies and use artificial intelligence applications to carry out operations (Satalkin \& Steiner, 2020). That enabled companies to identify customer needs and meet customer demands within a short duration of time (Nambisan, 2017). It improved the companies' competitiveness in the environment that is highly competitive. It enables companies to design products and services in a manner that meet the customer interests. It enabled companies to provide customers with creative solutions within a short period of time. It enabled companies to provide such solutions in a manner that meet the environmental quality standards (Rathee, 2017). Due to the Coronavirus crisis, the global economy in general and the Jordanian economy in particular has been facing many challenges. Thus, Jordanian agricultural companies in

* Corresponding author.

E-mail address: elham.alhiary@bau.edu.jo (E. Alhiary) 
Jordan Valley have been exerting much effort to retain their customers. Such efforts include: meeting the environmental quality standards (Ormazabal et al., 2018). Jordan Valley provides Jordanians and exporters with a major amount of vegetables. That's because Jordan Valley has a special climate due to being the lowest place below sea level in the world. Since the emergence of the Coronavirus, agricultural companies in Jordan Valley have been practicing digital entrepreneurship to meet environmental quality standards.

\subsection{Statement of the Problem}

According to Nimbeo website, Jordan has been suffering from many environmental problems. Thus, there is a high need for meeting the environmental quality standards in Jordan. During 2020 , Jordan was ranked $70^{\text {th }}$ on world ranking in terms of the extent of the severity of pollution. The pollution index of Jordan during 2020 is 75.98 . The decline in pollution level in Jordan in 2020 is attributed to the lockdown measures carried out due to the coronavirus crisis. Such measures led to holding the operations of economic companies temporarily. During 2019, Jordan was ranked $115^{\text {th }}$ on world ranking in terms of the extent of the severity of pollution. During 2019, Jordan was ranked second on Arab world ranking in terms of the extent of the severity of pollution. The pollution index of Jordan during 2019 is 85.73 . The pollution index of Jordan during 2016 is 82.72 . The pollution index of Jordan during 2015 is 85.64 which means that pollution has been increasing in Jordan. That means that the degree to which Jordanian companies have been meeting environmental quality standards has been declining.

The study's problem is represented in the questions below

Q.1. What is the environmental quality level of agricultural companies in Jordan Valley?

Q.2. What is the impact of digital entrepreneurship on the environmental quality of agricultural companies in Jordan Valley?

\subsection{The Study's Significance}

This study is significant because of the significance of digital entrepreneurship. For instance, digital entrepreneurship is the most effective means for enabling agricultural companies to carry out their operations efficiently. This study is significant because the role of digital entrepreneurship in environmental quality isn't clear in agricultural companies. It is significant because Jordan Valley is very significant. For instance, Jordan Valley is the widest agricultural area. It is significant because it provides the top management of agricultural companies with information about digital entrepreneurship and its impact on environmental quality. Such information shall enable agricultural companies to improve their performance and environmental quality.

\subsection{The Study's Goals}

This study aimed to 1)- Identify the environmental quality level of agricultural companies in Jordan Valley.

2)- Identify the impact of digital entrepreneurship on the environmental quality of agricultural companies in Jordan Valley.

\subsection{Literature Review \& Hypothesis Development}

Warrick (2018) investigated the extent to which the employees' pro-environmental behaviour relates to their protection motivation, organizational identification, and perception and knowledge of the organization's CSR and EMS in the USA. He aimed to explore the impact of internal and organizational factors on employee environmental behaviour. An online survey was used. Pearson correlation coefficient values were calculated. The latter researcher found that all the independent variables had a significant positive relationship with employee pro-environmental behaviour. He found that the economic dimension of corporate social responsibility affected employee motivation. He recommends improving the environmental performance and utilizing natural resources efficiently. Boren (2016) investigated the degree to which the organizations understood the common meanings and application of sustainability. He the degree to which the organizations use modern theories to improve the organizational culture. He found that leaders in organizations affect employee behaviour and exchange of cultural meanings and practices in US organizations. He used a mixed methodology. He used a questionnaire and observation method. He found that the extent of using environmental systems is affected by the degree to which the organizations understood such systems. He recommends developing the organizational cultures to develop environmental management. Garza-Reyes et al. (2018) investigated the role of environment management in raising the sustainability of environmental resources based on international standards related to environmental quality. He aimed to shed a light on environmental management in Chinese industrial organizations and green production. He surveyed 119 Chinese companies. He used a questionnaire and adopted a descriptive approach. Several results were reached. For instance, it was found that the extent of awareness about environmental quality standards is low. The researcher recommends developing the expertise of technical and administrators through providing them with courses. Such courses must provide them with knowledge about environmental quality standards and the way of meeting them. Famiyeh and Kwarteng (2018) explored the impact of environmental strategies on mining and supply chain. They explored the factors that affect environmental management in mining organizations in Ghana. They adopted an exploratory approach. The population consists of mining organizations. They used a questionnaire and adopted a descriptive approach. They reached several results. They found that the organizational bodies supervising environmental systems show a good performance. Such bodies motivate employees in organizations to show attention to environmental resources and utilize them optimally. The latter researchers recommend exerting more effort by the employees enforcing control over the implementation 
of environmental policies in the mining factories. Passetti et al. (2018) explored the degree to which the implementation of internal environmental management and voluntary environmental information is related to organizational change. They used a survey to collect data from several Italian companies and conducted several interviews. They adopted a descriptive approach. They reached several results. They found that the targeted companies focus much on the implementation of internal environmental management and voluntary environmental information. They recommend conducting studies about the external and internal organizational environments. They recommend setting effective policies in the aim of practicing environmental management effectively. Famiyeh et al. (2018) explored the role of environmental management practices (EMP), operational competitiveness and environmental performance. Those variables affect environmental quality in organizations. The population consists of experts in developing countries. The survey-based approach was adopted. A survey was used. Several results were reached. For instance, the researchers found that the environmental quality positively affects the organizational performance of organizations. They found that the environmental quality positively affects the competitiveness policies. They recommend providing employees in the organization in developing countries with incentives to encourage them to implement the environmental management systems. They add that providing such incentives shall contribute to utilizing environmental resources optimally. Satalkin and Steiner (2020) explored the impact of digital entrepreneurship on innovation and making transformations in business organization. They reviewed the relevant studies (i.e. 52 studies). Those studies shed a light on digital entrepreneurship. It was found that the factors that affect digital entrepreneurship are:1)- The innovation system. 2)the process of practicing entrepreneurship (including the organizational management activities, transformations to operational strategies activities and establishing digital companies). 3)-The relevant environmental system (the impact of infrastructure and other institutions). Rathee (2017) aimed to explore the impact of the internet from the perspective of entrepreneurs. This impact is represented in keeping up with the developments in the digital world. The researcher found that the using digital technology by entrepreneurs shall enable them to achieve success. He found that the use of ICTs by small and middle sized companies enabled them to achieve success and provided them with new opportunities.

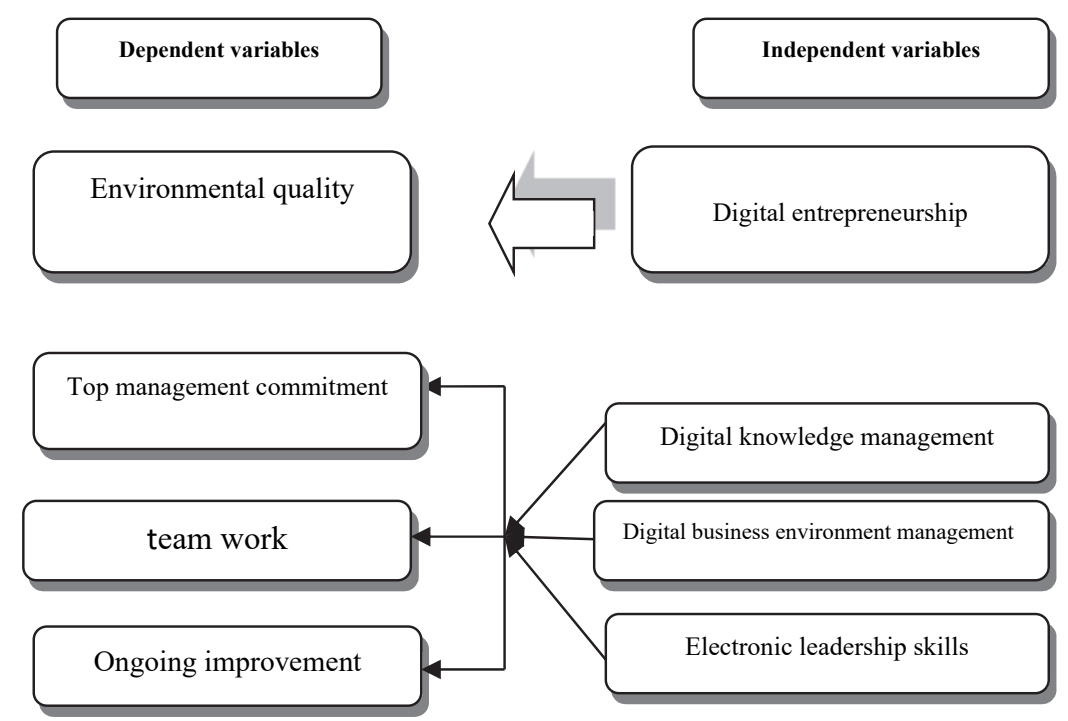

Fig. 1. Research Model

In the light of the aforementioned information, the researcher drafted the main hypothesis displayed below:

Main hypothesis: The digital entrepreneurship dimensions jointly don't have any statistically significant impact -at the statistical significance level of $(\alpha \leq 0.05)$ on the environmental quality dimensions jointly in agricultural companies.

To test the main hypothesis, the following sub-hypotheses were drafted:

$\mathbf{H}_{01}$ : Digital entrepreneurship dimensions (i.e. digital knowledge management, digital business environment management, and electronic leadership skills) don't have any statistically significant impact on top management commitment in agricultural companies.

$\mathbf{H}_{\mathbf{0} 2}$ : Digital entrepreneurship dimensions (i.e. digital knowledge management, digital business environment management, and electronic leadership skills) don't have any statistically significant impact on team work in agricultural companies.

H03: Digital entrepreneurship dimensions (i.e. digital knowledge management, digital business environment management, and electronic leadership skills) don't have any statistically significant impact on ongoing improvement in agricultural companies. 


\section{Theoretical framework}

\subsection{Digital entrepreneurship}

According to Hull et al. (2007) and Kraus et al. (2019), digital entrepreneurship is a significant term due to the major technological developments (Hull et al., 2007; Kraus et al., 2019). Such developments require shifting to the use of electronic applications and modern technologies. Therefore, governments become keen on keeping up with the latest digital development. For instance, all ministries today use ICT (Horak et al., 2019). Ngoasong (2018) adds that social media fostered the prevalence of digital entrepreneurship. Due to such prevalence, many companies adjusted their organizational structures and business operations in a manner that fits with the new digital developments(Giones \& Brem, 2017). Digital entrepreneurship played a significant role in developing companies. For instance, companies can do many operations through digital technologies (Giones \& Brem, 2017). According to Hull et al. (2007) and Horak et al. (2019), digital entrepreneurship refers to all the organizational activities that are related to shifting to the use of digital technologies for carrying out operations, including ICT and social media. Nambisan (2017) and Giones and Brem (2017) add that digital entrepreneurship is a process that involves building successful interactive relationships with investors and financiers via networks and electronic communities. Such relationships should be created in a manner that simulate relationships in reality. They should be created in a manner that enables companies to earn more profits, attract more customers, and deliver services of high quality within a short duration of time (Nambisan, 2017; Giones \& Brem, 2017). Giones and Brem (2017) and Li et al. (2017) add that digital entrepreneurship aims at meeting two goals. These goals are: 1)-searching for available opportunism. 2)- transferring data and information through using artificial intelligence. According to Ngoasong (2018), the European Council adds that digital entrepreneurship has three dimensions. Those dimensions are:

1)- Digital knowledge management: It refers to the process of acquiring knowledge and expertise through exchanging information and data through technological means and applications and the technological community. It involves establishing digital knowledge database that enable companies to generate and acquire knowledge through digital means

2)- digital business environment management: It refers to the process that involves organizing the processes related to digital entrepreneurship in electronic communities. It enables companies to manage and organize their processes in a manner that fits with their human resources, and scope of work, and volume of works. It enables companies to manage and organize their processes in a manner that enables them to have successful relationships

3)- electronic leadership skills: They refer to the skills that enable companies to improve their electronic environment and generate digital information. They enable companies to have efficient digital leadership and manage their operations in an electronic manner

\subsection{Environmental quality}

According to Passetti et al. (2018), environmental quality management involves a set of modern management concepts. It enables companies to achieve improvements in an ongoing manner. It enables companies to meet the customer demands and expectations in a manner that doesn't cause harm to the environment. According to Famiyeh et al. (2018), environmental quality involves making changes to the companies' activities in a manner that contributes to fighting against environmental pollution and turns the companies into environmentally friendly companies. According to Boren (2016), quality plays an essential role when making environmental plans by companies and enforcing environmental control. Ormazabal et al. (2018) add that many laws were enacted to raise environmental quality. Such laws contribute to preserving the environment. In addition, many associations were established to enforce environmental control and defend the environment. Famiyeh and Kwarteng (2018) adds that environmental quality has been receiving much attention by the owners of companies worldwide. That's because companies need to achieve development in the environmental field. For instance, companies need to provide customers with safe and secure products. Warrich (2016) adds that much attention has been provided to environmental quality after holding the Stockholm conference in 1972. Adopting environmental quality systems shall enable companies to compete in local and global markets. Through adopting such systems, companies can comply with environmental quality standards (Boren, 2016). Boren (2016) adds that environmental quality has become the driving force for all the operations and activities of companies. Environmental quality has become linked with all the functions in companies. It has become one of the issues that gain the greatest attention. Boren (2016) adds that environmental problems have become a challenge facing humans and environment. Thus, companies of various types and sizes have been providing much attention to environmental quality. Ormazabal et al. (2018) add that many companies take environmental issues into consideration when conducting feasibility studies. That's because companies don't want to cause harm to the environment nor pollute the environment in any manner.

Dawood (2018) adds that the term (environmental quality) emerged in 1990. This term was used for the first time by the environmental management institute in order to encourage companies to practice environmental management willingly. Passetti et al. (2018) add that environmental quality is a methodology that involves environmental management and quality management. Environmental quality aims at fighting against pollution as being one of the shortcomings of total quality management. Biscotti et al. (2018) add that environmental quality is a methodology involving the principles of environmental management and the principles of total quality management (Boren, 2016). Environmental quality aims at developing companies in environmental areas. It aims at managing the negative impacts of the company's operations on the environment. It aims at 
identifying how covenant the product is for use and how safe the product is for human health and environment. It aims at assessing the product. Garza-Reyes et al. (2018) add that environmental quality is a set of standards that shed a light mainly on the pollution derived from the company's operations and activities. Environmental quality aims at enforcing control over companies' activities. It aims at setting rules for fighting against the pollution derived from companies' activities (Famiyeh \& Kwarteng, 2018). It contributes to utilizing the things that are lifted after carrying out companies' activities (Famiyeh \& Kwarteng, 2018). It is a concept that is based on the principles of total quality management. It provides attention to several environmental elements (air, water, soil, etc.). It provides attention to the operational, economic and environmental aspects of companies' activities.

\subsubsection{Requirements of achieving environmental quality}

\subsubsection{Top management commitment}

The top management is the one concerned the most in implementing the environmental policies and providing human and financial potentials for such implementation. Implementing such policies aim at showing compliance with laws and regulations and preventing pollution. It is essential for raising environmental quality and achieving a high environmental quality level. It is essential for providing environment-friendly products (Boren, 2016). The top management commitment to implementing environmental quality policies is essential. According to Famiyeh and Kwarteng (2018), it plays a significant role in encouraging employees to show compliance in implementing the environmental quality systems. The top management must turn the environmental quality into a prevalent philosophy within the individuals' mind. It must ensure that environmental quality falls under the interests and responsibilities of individuals. Garza-Reyes et al. (2018) and Famiyeh and Kwarteng (2018) add that the top management is the one that must follow up the process of implementing the environmental quality systems by employees and encourage employees to implement them. The top management must provide employees with training about that. Such training shall provide employees with skills and expertise that allow them to handle any challenge they face during such implementation. A high environmental quality level can't be achieved without receiving support and showing compliance by the top management. To illustrate more, the top management must comply with the relevant laws, policies, and regulations related to environmental quality.

\subsubsection{Ongoing improvement}

According to Warrick (2016) and Passetti et al. (2018), ongoing improvementis a management-related philosophy that aims at developing companies' operations and activities and raises the environmental quality of companies. It is considered essential when implementing environmental policies efficiently. That's because companies should seek avoiding pollution fully. It's essential because the top management always seek developing products and operations. It is considered as an effective means for raising the environmental quality in companies. It aims at ensuring that the company doesn't cause any pollution (Famiyeh \& Kwarteng, 2018). It grants the top management the capability to fight against pollution gradually. It requires encouraging employees to refrain from causing pollution. It is considered essential to implement the environmental policies that aim at refraining from causing pollution. It involves several activities that aim to increase the environmental quality level.

\subsubsection{Team work}

According to Ormazabal et al. (2018) and Abdalla and Albuhisi (2018), teamwork is an effective modern means for practicing environmental quality management efficiently. It contributes to achieving a high environmental quality level. Various teams were formed in companies to provide attention to the process of achieving a high environmental quality level (Boren, 2016). That is done in the aim of developing the employees' teamwork skills. It's done in the aim of making developments that aim at achieving a high environmental quality level. According to Biscotti et al. (2018) and Dang (2019), team work refers to working with a team spirit. It is considered essential for making ongoing improvements. It allows individuals to share their expertise and skills with others. It positively affects the outcomes of the plans (Samuel \& Amoako, 2018). It is considered essential to fight against environmental pollution. The work team must include managers of various management levels, including: managers from the top-level management.

\section{The study's methodology}

The researcher adopted a quantitative approach that fits with the nature of the study's questions and hypotheses. She used a questionnaire. The questionnaire forms were distributed to a sample selected from the agricultural companies in Jordan Valley. This sample consists from several (project managers, CEOs, heads of departments, engineers, and supervisors and technicians). The researcher adopted a descriptive approach and used the SPSS program to analyse data.

\subsection{The reliability of the instrument}

To measure the reliability of the instrument, the Cronbach alpha coefficient values were calculated. They were calculated to measure the internal consistency. Table 1 presents the Cronbach alpha coefficient values. Those values are within the range of $(0.884-0.951)$. They indicate that the instrument is reliable. That's because all the values are greater than 0.70 . 
Table 1

The Cronbach alpha coefficient values

\begin{tabular}{lll}
\hline Variable & Number of items & The Cronbach alpha coefficient value \\
\hline Digital knowledge management & 6 & 0.913 \\
Digital business environment management & 5 & 0.909 \\
Electronic leadership skills & 4 & 0.884 \\
Top management commitment & 8 & 0.932 \\
Team work & 7 & 0.920 \\
Ongoing improvement & 10 & 0.951 \\
\hline \multicolumn{1}{c}{ Overall } & 40 & 0.984 \\
\hline
\end{tabular}

Based on the table above, the overall value is 0.954 . The values are within the range of $(0.884-0.951)$. They are greater than $60 \%$. Thus, the instrument is highly reliable and valid

\subsection{Statistical analysis}

Means and standard deviations are calculated to answer the study's questions. The multiple regression analysis and the simple regression analysis were conducted to test the sub-hypotheses.

\section{Checking the fitness of the model}

First: Multicollinearity: Pearson correlation coefficient values of the dimensions of the independent variables are calculated. That is done to ensure that there isn't any multicollinearity problem. Table (2) presents the latter values

Table 2

The Pearson correlation coefficient values of the dimensions of the independent variable (i.e. digital entrepreneurship)

\begin{tabular}{llll}
\hline Dimensions of digital entrepreneurship & Digital knowledge management & Digital business environment management & Electronic leadership skills \\
\hline Digital knowledge management & 1.000 & & \\
Digital business environment management & $0.786^{* *}$ & 1.000 & 1.000 \\
Electronic leadership skills & $0.830^{* *}$ & $* * 0.857$ & \\
\hline
\end{tabular}

$(*)$ : This sign means that the value is statistically significant at the statistical significance level of 0.01

Based on Table 2, the highest value is 0.857 . It's the value of the correlation between digital business environment management and electronic leadership skills. However, all the other values are lower than 0.857 . That indicates that there isn't any multicollinearity problem between the dimensions of the independent variable. The variance inflation factor values and tolerance values were calculated to ensure there isn't any multicollinearity problem between the dimensions of the independent variable. They are displayed in Table 3.

\section{Table 3}

The variance inflation factor values and tolerance values of the dimensions of the independent variable (i.e. digital entrepreneurship)

\begin{tabular}{lll}
\hline Variable & Tolerance values & The variance inflation factor values (VIF) \\
\hline Digital knowledge management & .290 & 3.452 \\
Digital business environment management & .248 & 4.032 \\
Electronic leadership skills & .202 & 4.947 \\
\hline
\end{tabular}

\section{Table 4}

Pearson correlation coefficient values of the dimensions of the dependent variable (i.e. the environmental quality)

\begin{tabular}{llll}
\hline The dimensions of environmental quality & Top management commitment & Team work & Ongoing improvement \\
\hline Top management commitment & 1.000 & & \\
Team work & $.922^{* *}$ & 1.000 & $.902^{* *}$ \\
Ongoing improvement & $.882^{* *}$ & 1.000 & \\
\hline * ?
\end{tabular}

(*): This sign means that the value is statistically significant at the statistical significance level of 0.01

Based on Table 4, the highest Pearson correlation value is 0.922 . It represents the correlation existing between team work and top management commitment. The other correlation values are less than 0.922 . The variance inflation factor values and tolerance values were calculated to ensure there isn't any multicollinearity problem between the dimensions of the dependent variable (i.e. environmental quality). They are displayed in Table 5.

Table 5

The variance inflation factor values and tolerance values of the dimensions of the dependent variable (i.e. environmental quality)

\begin{tabular}{lcc}
\hline Variable & Tolerance values & The variance inflation factor values (VIF) \\
\hline Top management commitment, & .137 & 7.307 \\
Team work & .115 & 8.710 \\
Ongoing improvement & .170 & 5.897 \\
\hline
\end{tabular}


Based on Table 5, the VIF values are greater than 1 and less than 10. In addition, the tolerance values are within the range of $(0-1)$. Thus, there isn't multicollinearity problem between the dimensions of the dependent variable (i.e. environmental quality).

\subsection{Normal distribution}

Table 6

Checking the normal distribution of data through calculating the Skewness values and Kurtosis values. Those values are shown below

\begin{tabular}{lll}
\hline Area & Skewness value & Kurtosis value \\
\hline Digital entrepreneurship & 480. \\
Digital knowledge management & 283. & 293. \\
Digital business environment management & $690 .-$ & 073. \\
Electronic leadership skills & $398 .-$ & $057 .-$ \\
Environmental quality & $488 .-$ & 1.371 \\
Top management commitment & 283. & 373. \\
Team work & $678 .-$ & 1.567 \\
Ongoing improvement & $825 .-$ & 1.122 \\
\hline
\end{tabular}

Based on the table above, all the Skewness values are less than -1 . That indicates that the values are normally distributed. Thus, data can be analyzed statistically. Durbin-Watson statistical test was conducted to ensure that there is not any autocorrelation problem in the data. Through this test, the tabulated $\mathrm{D}-\mathrm{W}$ values of a sample $(\mathrm{n}=72)$ were compared with the calculated D-W values. The highest tabulated D-W value is abbreviated as (du) and the lowest tabulated D-W value is abbreviated as $(\mathrm{dL})$. In case the calculated $\mathrm{D}-\mathrm{W}$ value doesn't fall under the range of $\mathrm{d}_{\mathrm{L}}$ values and du values, there isn't any autocorrelation problem (Montgomery et al., 2006, 477-478). Table 7 presents the results of the Durbin-Watson statistical test.

Table 7

The Durbin-Watson statistical test

\begin{tabular}{ccccl}
\hline Hypothesis & calculated $\mathbf{D}-\mathbf{W}$ value & lowest value $\left(\mathbf{d}_{\mathbf{L}}\right)$ & Highest value $\left(\mathbf{d}_{\mathbf{u}}\right)$ & Result \\
\hline $\mathrm{H}_{01}$ & 1.966 & 1.54 & 1.75 & There is not any auto-correlation problem \\
$\mathrm{H}_{01-1}$ & 2.458 & 1.57 & 1.68 & There is not any auto-correlation problem \\
$\mathrm{H}_{01-2}$ & 2.277 & 1.57 & 1.68 & There is not any auto-correlation problem \\
$\mathrm{H}_{01-3}$ & 2.103 & 1.57 & 1.68 & There is not any auto-correlation problem \\
\hline
\end{tabular}

Based on Table 7, the calculated D-W values don't fall under the range of $d_{L}$ values and du values. Thus, there is not any auto-correlation problem in the data. Thus, data can be used for carrying out regression analysis.

\section{Discussion and analysis}

Population

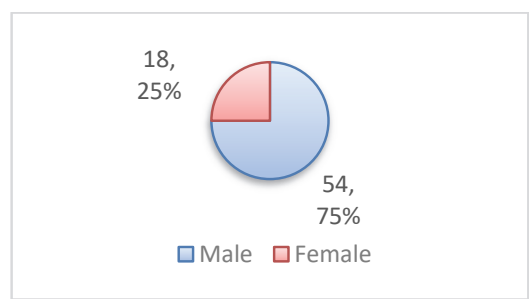

Gender

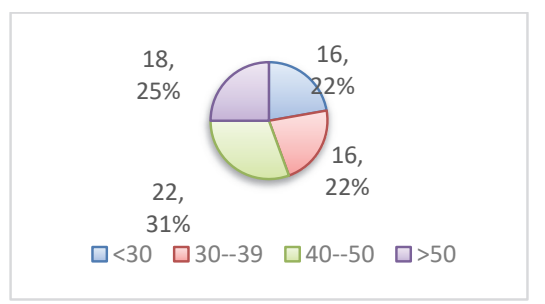

Age

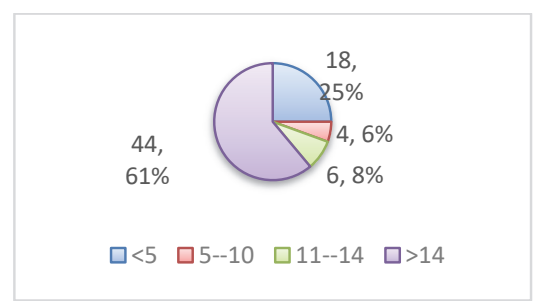

Job experience

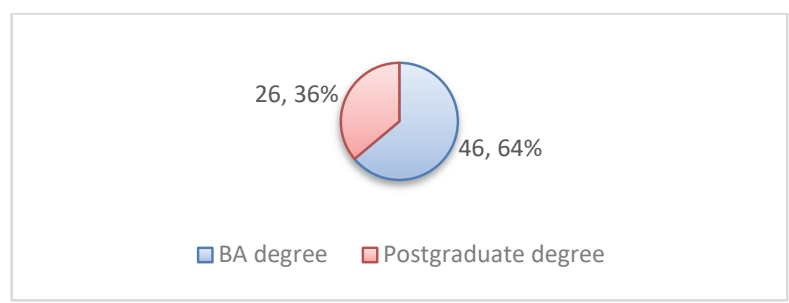

Academic qualification

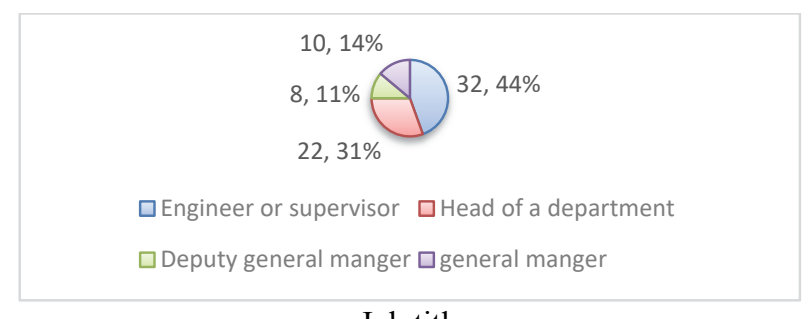

Job title

Fig. 1. Characteristics of the study's population 
Table 8

Means and standard deviations of the respondents' attitudes in terms of each area

\begin{tabular}{lllll}
\hline No. & Item & Mean & Std. & Level \\
\hline 1 & Digital knowledge management & 3.48 & 1.074 & Moderate \\
2 & Digital business environment management & 3.36 & 1.022 & Moderate \\
3 & Electronic leadership skills & 3.17 & 1.097 & Moderate \\
6 & Top management commitment & 3.39 & 1.069 & Moderate \\
5 & Team work & 3.48 & 0.937 & Moderate \\
4 & Ongoing improvement & 3.39 & 0.982 & Moderate \\
\hline
\end{tabular}

\section{Digital knowledge management}

The researcher found that the targeted companies show support to practicing digital entrepreneurship. She found that the targeted companies develop the skills related to digital entrepreneurship. She found that the targeted companies don't provide talented employees with invectives. That's because the targeted companies suffer from fluctuations in the cash flow.

\section{Digital business environment management}

The researcher found that the targeted companies don't provide support to the digital business environment management. That's attributed to the nature of the works carried out by these companies. To illustrate more, doing the work of those companies requires working in the field. Such lack of support may be attributed to the fact that technologies are still incapable of meeting the environmental control requirements of those companies.

\section{Electronic leadership skills}

The researcher found that the targeted companies exert much effort to develop employees' electronic leadership skills. However, due to the need of these companies to carry out field works, companies suffer from a high workload. That hinders the employees from developing such skills.

\section{The top management commitment}

The researcher found that the top management of the targeted companies comply much with the laws and regulations that are related to environmental quality. She also found that such management are keen on promoting awareness among employees about the significance of complying with such laws and regulations. She found that such management is keen on using environment-friendly technologies. She found that the degree to which such management delegates powers to employees is moderate. That's attributed to the nature of the challenges faced by such companies. Most of the agricultural lands are located in remote areas.

\section{Team work}

The researcher found that the targeted companies are keen on meeting the customer demands. That's because meeting customer demands shall enable companies to gain profit and have a good reputation. The researcher found that the degree to which the targeted companies seek improving their environment-related outcomes, ideas and policies is moderate. She found that the degree to which the targeted companies take feedback into consideration is moderate.

\section{Ongoing improvement}

The researcher found that the targeted companies exert much effort to make improvements in an ongoing manner. She found that the targeted companies exert much effort to improve customer services and achieve a high customer satisfaction level. The targeted companies seek achieving that through establishing work teams and periodical holding meetings with farmers. They seek achieving that through engaging farmers in the process of developing new services. However, the challenges facing farmers during the farming seasons hinder the targeted companies from meeting such goals. Due to such challenges, farmers in Jordan Valley seek planting in Mafraq. That negatively affects the ability to engage farmers in the processes that aim at making improvements in an ongoing manner.

\subsection{Testing the study's hypotheses}

Main hypothesis: The digital entrepreneurship dimensions jointly don't have any statistically significant impact -at the statistical significance level of $(\alpha \leq 0.05)$ - on the environmental quality dimensions jointly in agricultural companies. To test the above hypothesis, the multiple regression analysis was conducted. Table 9 presents the results of the latter analysis 
Table 9

The results of the multiple regression analysis to test the main hypothesis

\begin{tabular}{lcc}
\hline Dimensions of independent variable & \multicolumn{2}{c}{ Regression coefficient $^{\text {a }}$} \\
\cline { 2 - 3 } & B value & T value \\
\hline Digital knowledge management & 0.269 & 4.095 \\
Digital business environment management & 0.416 & 5.723 \\
Electronic leadership skills & 0.201 & 0.000 \\
\hline
\end{tabular}

*a: Independent variable (i.e. digital entrepreneurship) $\quad$ b: Dependent variable (environmental quality)

$\mathrm{R}=0.944 \mathrm{R}^{2}=0.891 \quad \mathrm{~F}$-value $=186.003(0.000)$

Based on the table above, the calculated t-values are within the range of $2.704-5.723$. They are statistically significant at the statistical significance level of $(a \leq 0.05)$. Thus, the digital entrepreneurship dimensions jointly have a statistically significant impact -at the statistical significance level of $(\alpha \leq 0.05)$ - on the environmental quality dimensions jointly in agricultural companies. The correlation coefficient $(\mathrm{R})$ value between digital entrepreneurship dimensions and environmental quality is 0.944 . The determination coefficient $\left(\mathrm{R}^{2}\right)$ value between digital entrepreneurship dimensions and environmental quality is 0.891 . Thus, $89.1 \%$ of the changes in the environmental quality level can be attributed to digital entrepreneurship dimensions. The calculated $\mathrm{f}$ value is 168.003 which is a statistically significant impact -at the statistical significance level of ( $\alpha \leq 0.05)$. To identify the degree to which the environmental quality is affected by each digital entrepreneurship dimension, the stepwise multiple regression analysis. Table 10 present the results of the latter analysis.

Table 10

The results of the stepwise multiple regression analysis for exploring the degree to which the environmental quality is affected by each digital entrepreneurship dimension

\begin{tabular}{|c|c|c|c|c|c|}
\hline \multirow[t]{2}{*}{ Model no. } & \multicolumn{2}{|r|}{ Model summary } & \multicolumn{3}{|l|}{ Variance } \\
\hline & Correlation coefficient (R) & Determination coefficient (R2) & Degree of freedom & F value & Sig. F \\
\hline 1 & 0.904 & 0.818 & 1 & 314.269 & 0.000 \\
\hline 2 & 0.938 & 0.880 & 2 & 252.279 & 0.000 \\
\hline 3 & 0.944 & 0.891 & 3 & 186.003 & 0.000 \\
\hline
\end{tabular}

Model No:

1)- digital business environment management

2)- digital business environment management; and digital knowledge management

3)- digital knowledge management, digital business environment management, and electronic leadership skills

Based on the table above, $81.8 \%$ of the changes in the environmental quality can be attributed to digital business environment management. $88 \%$ of the changes in the environmental quality can be attributed to digital knowledge management. $89.1 \%$ of the changes in the environmental quality can be attributed to electronic leadership skills. Based on such values, the null hypothesis is rejected and the alternative hypothesis is accepted. That means that digital entrepreneurship dimensions jointly have a statistically significant impact - at the statistical significance level of $(a \leq 0.05)$ - on the environmental quality dimensions jointly in agricultural companies.

\section{Table 11}

The stepwise multiple linear regression analysis for exploring the impact of digital entrepreneurship dimensions jointly on environmental quality level

\begin{tabular}{|c|c|c|c|c|}
\hline \multirow[t]{2}{*}{ Model } & & \multicolumn{3}{|c|}{ Regression coefficient } \\
\hline & & B value & $\mathrm{T}$ value & Sig .T \\
\hline 1 & Digital business environment management & 0.819 & 17.728 & 0.000 \\
\hline \multirow{2}{*}{2} & Digital business environment management & 0.532 & 8.694 & 0.000 \\
\hline & Digital knowledge management & 0.356 & 5.957 & 0.000 \\
\hline \multirow{3}{*}{3} & Digital business environment management & 0.416 & 5.723 & 0.000 \\
\hline & Digital knowledge management & 0.269 & 4.095 & 0.000 \\
\hline & Electronic leadership skills & 0.201 & 2.704 & 0.009 \\
\hline
\end{tabular}

Based on the table above, the significance values are within the range of (0.00-0.009). They are less than 0.05 . They are statistically significant-at the statistical significance level of $(a \leq 0.05)$. Thus, the null hypothesis is rejected and the alternative hypothesis is accepted. That means that digital entrepreneurship dimensions jointly have a statistically significant impact -at the statistical significance level of $(\mathrm{a} \leq 0.05)$ - on the environmental quality dimensions jointly in agricultural companies.

\subsection{Testing the study's sub-hypotheses}

$\mathrm{H}_{01}$ : Digital entrepreneurship dimensions (i.e. digital knowledge management, digital business environment management, and electronic leadership skills) do not have any statistically significant impact -at the statistical significance level of ( $\alpha \leq 0.05)$ on top management commitment in agricultural companies. To test the above hypothesis, the simple regression analysis was conducted. The results of the latter analysis are presented through Table 12. 
Table 12

The results of the simple regression analysis for testing the first sub-hypothesis

\begin{tabular}{|c|c|c|c|c|c|c|c|c|}
\hline \multirow{2}{*}{$\begin{array}{l}\text { Dependent } \\
\text { variable }\end{array}$} & \multicolumn{2}{|c|}{ Model summary } & \multicolumn{3}{|c|}{ Variance $^{\mathrm{b}}$} & \multicolumn{3}{|c|}{ Regression coefficient $^{a}$} \\
\hline & $\begin{array}{l}\text { Correlation co- } \\
\text { efficient }(\mathrm{R})\end{array}$ & $\begin{array}{l}\text { Determination co- } \\
\text { efficient }\left(\mathrm{R}^{2}\right)\end{array}$ & Degree of freedom & $\mathrm{F}$ value & Sig. F & $B$ value & $\mathrm{T}$ value & Sig. T. \\
\hline \multirow{3}{*}{$\begin{array}{l}\text { Independent } \\
\text { variable }\end{array}$} & & & Regression & & & & & \\
\hline & $.911 \mathrm{a}$ & .830 & Residuals & 341.147 & $.000 \mathrm{a}$ & .927 & 18.470 & .000 \\
\hline & & & Total & & & & & \\
\hline
\end{tabular}

*a: Independent variable (i.e. digital entrepreneurship). b: Dependent variable (i.e. top management commitment)

Based on the table above, the correlation coefficient $(\mathrm{R})$ value of the correlation between digital entrepreneurship and top management commitment is 0.911 . Thus, there is a positive relationship between those variables. The determination coefficient $\left(\mathrm{R}^{2}\right)$ is 0.830 . Thus, $83 \%$ of the changes in the top management commitment can be attributed to digital entrepreneurship. The calculated $F$ value is 341.147 which is statistically significant-at the statistical significance level of $(\alpha \leq 0.05)$. Thus, the null hypothesis is rejected and the alternative hypothesis is accepted. That means that digital entrepreneurship dimensions (i.e. digital knowledge management, digital business environment management, and electronic leadership skills) have a statistically significant impact - at the statistical significance level of $(\mathrm{a} \leq 0.05)$ - on top management commitment in agricultural companies.

$\mathrm{H}_{02}$ : Digital entrepreneurship dimensions (i.e. digital knowledge management, digital business environment management, and electronic leadership skills) don't have any statistically significant impact -at the statistical significance level of ( $\alpha \leq 0.05)$ - on team work in agricultural companies

To test the above hypothesis, the simple regression analysis was conducted. The results of the latter analysis are presented through Table 13.

Table 13

The results of the simple regression analysis for testing the second sub-hypothesis

\begin{tabular}{|c|c|c|c|c|c|c|c|c|}
\hline \multirow[t]{2}{*}{ Dependent variable } & \multicolumn{2}{|c|}{ Model summary } & \multicolumn{3}{|c|}{ Variance $^{b}$} & \multicolumn{3}{|c|}{ Regression coefficient $^{a}$} \\
\hline & $\begin{array}{c}\text { Correlation } \\
\text { coefficient (R) }\end{array}$ & $\begin{array}{l}\text { Determination co- } \\
\text { efficient (R2) }\end{array}$ & Degree of freedom & F value & Sig. F & B value & $\mathrm{T}$ value & Sig. T. \\
\hline $\begin{array}{l}\text { Independent } \\
\text { variable }\end{array}$ & $.895 \mathrm{a}$ & .802 & $\begin{array}{c}\text { Regression } \\
\text { Residuals } \\
\text { Total }\end{array}$ & 282.709 & $.000 \mathrm{a}$ & .815 & 16.814 & .000 \\
\hline
\end{tabular}

Based on the table above, the correlation coefficient $(\mathrm{R})$ value of the correlation between digital entrepreneurship and team work is 0.895 . Thus, there is a positive relationship between those variables. The determination coefficient $\left(\mathrm{R}^{2}\right)$ is 0.802 . Thus, $80.2 \%$ of the changes in the team work can be attributed to digital entrepreneurship. The calculated $\mathrm{F}$ value is 282.709 which is statistically significant-at the statistical significance level of $(\alpha \leq 0.05)$. Thus, the null hypothesis is rejected and the alternative hypothesis is accepted. That means that the digital entrepreneurship dimensions (i.e. digital knowledge management, digital business environment management, and electronic leadership skills) have a statistically significant impact -at the statistical significance level of $(\alpha \leq 0.05)$ - on team work in agricultural companies.

$\mathrm{H}_{03}$ : Digital entrepreneurship dimensions (i.e. digital knowledge management, digital business environment management, and electronic leadership skills) don't have any statistically significant impact -at the statistical significance level of (a $\leq 0.05)$ - on ongoing improvement in agricultural companies.

To test the above hypothesis, the simple regression analysis was conducted. The results of the latter analysis are presented through Table 14.

Table 14

The results of the simple regression analysis for testing the third sub-hypothesis

\begin{tabular}{|c|c|c|c|c|c|c|c|c|c|}
\hline \multirow[t]{2}{*}{ Dependent variable } & \multicolumn{2}{|l|}{ Model summary } & \multicolumn{3}{|l|}{ Variance $^{\mathrm{b}}$} & \multicolumn{4}{|c|}{ Regression coefficient $^{\mathrm{a}}$} \\
\hline & $\begin{array}{l}\text { Correlation } \\
\text { coefficient (R) }\end{array}$ & $\begin{array}{l}\text { Determination co- } \\
\text { efficient (R2) }\end{array}$ & Degree of fr & & F value & Sig. F & B value & $\mathrm{T}$ value & Sig. T. \\
\hline $\begin{array}{l}\text { Independent } \\
\text { variable }\end{array}$ & $.917 \mathrm{a}$ & .841 & $\begin{array}{c}\text { Regression } \\
\text { Residuals } \\
\text { Total }\end{array}$ & $\begin{array}{c}1 \\
70 \\
71\end{array}$ & 371.006 & $.000 \mathrm{a}$ & .889 & 19.262 & .000 \\
\hline
\end{tabular}

*a: Independent variable (i.e. digital entrepreneurship). *b: dependent variable(i.e. ongoing improvement)

Based on the table above, the correlation coefficient $(\mathrm{R})$ value of the correlation between digital entrepreneurship and ongoing improvement is 0.917 . Thus, there is a positive relationship between those variables. The determination coefficient $\left(\mathrm{R}^{2}\right)$ is 0.841 . Thus, $84.1 \%$ of the changes in the ongoing improvement can be attributed to digital entrepreneurship. The calculated F value is 371.006 which is statistically significant-at the statistical significance level of $(\alpha \leq 0.05)$.

Thus, the null hypothesis is rejected and the alternative hypothesis is accepted. That means that digital entrepreneurship dimensions (i.e. digital knowledge management, digital business environment management, and electronic leadership skills) 
have a statistically significant impact -at the statistical significance level of $(a \leq 0.05)$ - on ongoing improvement in agricultural companies.

\section{Results}

The present study aimed to explore the impact of digital entrepreneurship on the environmental quality of agricultural companies in Jordan Valley. After analyzing data, the following results were reached:

1-The agricultural companies in Jordan Valley practice digital knowledge management. However, they have been facing many challenges in this regard. Such challenges are attributed to fluctuations of cash flow.

2-The agricultural companies in Jordan Valley practice digital business environment management in order to raise the environmental quality level. However, they have been facing challenges in this regard. Such challenges are attributed to the difficulty of practicing such management. They can be attributed to the differences between the work environments of employees

3-The agricultural companies in Jordan Valley seek improving their employees' electronic leadership skills. They seek that in the aim of raising the environmental quality level.

4-The agricultural companies in Jordan Valley have facing difficulties in improving their employees' electronic leadership skills in a manner that fits with the job requirements.

5-The top managements of the targeted companies are keen on meeting the requirements of environmental quality through complying with the laws. They are keen on promoting awareness among employees about the significance of complying with such laws and regulations. They are keen on providing employees with modern technologies to do their work.

6-The top managements of the targeted companies are keen on developing their employees' team work skills through promoting collaboration when making decisions and developing products.

7-The agricultural companies in Jordan Valley are keen on carrying out ongoing improvement in order to meet the customer demands in an ongoing manner and managing environmental risks.

\section{Recommendations}

The researcher recommends:

1)-Providing talented employees in agricultural companies with infinitives. That shall contribute to developing products and services.

2)- Providing more attention by agricultural companies to the design of administrative operations.

3)-Making a special budget for the training of talented employees in agricultural companies about the way of using modern technologies and applications. Such training must also aim at improving their electronic leadership skills.

4)-Delegating more power to the employees who work in agricultural companies in a manner that improves the implementations of environmental quality systems.

5)-Providing employees in agricultural companies with training courses about environmental quality.

\section{References}

Albuhisi, A. M., \& Abdallah, A. B. (2018). The impact of soft TQM on financial performance. International Journal of Quality \& Reliability Management, 35(7), 1360-1379.

Biscotti, A. M., D’Amico, E., \& Monge, F. (2018). Do environmental management systems affect the knowledge management process? The impact on the learning evolution and the relevance of organisational context. Journal of Knowledge Management, 22(3), 603-620.

Boren, B. (2016). Elaborating a Model of Cultural Exchange: An Investigation into the Relationship Between Organizational Cultures and the Adoption of Environmental Certified Management Standards.

Dang, W. V. (2019). Multi-criteria decision-making in the evaluation of environmental quality of OECD countries. International Journal of Ethics and Systems, 36(1), 119-130.

Famiyeh, S., Adaku, E., Amoako-Gyampah, K., Asante-Darko, D., \& Amoatey, C. T. (2018). Environmental management practices, operational competitiveness and environmental performance. Journal of Manufacturing Technology Management, 29(3), 588-600.

Famiyeh, S., \& Kwarteng, A. (2018). Implementation of environmental management practices in the Ghanaian mining and manufacturing supply chains. International Journal of Productivity and Performance Management, 67(7), $1091-1112$. 
Garza-Reyes, J. A., Yu, M., Kumar, V., \& Upadhyay, A. (2018). Total quality environmental management: adoption status in the Chinese manufacturing sector. The TQM Journal, 30(1), 2-19 .

Giones, F., \& Brem, A. (2017). Digital technology entrepreneurship: A definition and research agenda. Technology Innovation Management Review, 7(5).

Horak, S., Taube, M., Yang, I., \& Restel, K. (2019). Two not of a kind: Social network theory and informal social networks in East Asia. Asia Pacific Journal of Management, 36(2), 349-372.

Hull, C. E. K., Hung, Y. T. C., Hair, N., Perotti, V., \& DeMartino, R. (2007). Taking advantage of digital opportunities: a typology of digital entrepreneurship. International Journal of Networking and Virtual Organisations, 4(3), $290-303$.

Kraus, S., Palmer, C., Kailer, N., Kallinger, F., \& Spitzer, J. (2019). Digital Entrepreneurship. International Journal of Entrepreneurial Behavior \& Research, 25 (2), 353-375.

Li, W., Du, W., \& Yin, J. (2017). Digital Entrepreneurship Ecosystem As a New Form of Organizing: The Case of Zhongguancun. Frontiers of Business Research in China, 11(1), 5.

Nambisan, S. (2017). Digital Entrepreneurship: Toward a Digital Technology Perspective of Entrepreneurship. Entrepreneurship Theory and Practice, 41(6), 1029-1055.

Ngoasong, M. Z. (2018). Digital Entrepreneurship in a Resource-scarce Context: A Focus on Entrepreneurial Digital Competencies. Journal of Small Business and Enterprise Development, 25(3), 483-500.

Ormazabal, M., Viles, E., Santos, J., \& Jaca, C. (2018). An overview of environmental management in the Spanish food sector: a survey study. Management of Environmental Quality: An International Journal, 29(1), 49-62.

Passetti, E., Cinquini, L., \& Tenucci, A. (2018). Implementing internal environmental management and voluntary environmental disclosure. Accounting, Auditing \& Accountability Journal, 31(4), 1145-1173.

Rathee, R. (2017). Entrepreneurship the digital Era. Asia Pacific Journal of Research in Business Management, 8(6).

Satalkina, L., \& Steiner, G. (2020). Digital entrepreneurship and its role in innovation systems: A systematic literature review as a basis for future research avenues for sustainable transitions. Sustainability, 12(7), 2764.

Warrick, B. (2016). Examining employee motivation, environmental systems, and corporate social responsibility in proenvironmental behavior.

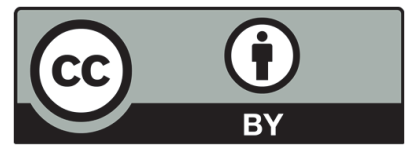

(C) 2021 by the authors; licensee Growing Science, Canada. This is an open access article distributed under the terms and conditions of the Creative Commons Attribution (CC-BY) license (http://creativecommons.org/licenses/by/4.0/). 